\title{
Percutaneous Renal Biopsy: Comparison of Blind and Real-time Ultrasound Guided Technique
}

\author{
Anil Pokhrel, ${ }^{1}$ Rajendra Kumar Agrawal, ${ }^{1}$ Anil Baral, ${ }^{1}$ Ajaya Rajbhandari, ${ }^{1}$ Rajani Hada ${ }^{1}$ \\ ${ }^{1}$ Department of Nephrology, National Academic of Medical Sciences, Bir Hospital, Kathmandu, Nepal.
}

\begin{abstract}
Background: Percutaneous renal biopsy is performed for diagnosis and prediction of prognosis of renal diseases. Adequacy of tissue and clinically significant bleeding are the main issues of the procedure. We aimed to compare these issues in renal biopsy by blind and real time ultrasound guided technique.

Methods: It was a cross sectional, randomized study conducted between June 2016 to December 2016. In blind technique, marking for biopsy was done by ultrasound. Two attempts were performed for all and more if tissue was inadequate. Patients kept in bed rest for 24 hours, observed for post procedure hematuria and ultrasound done at 6 hours and 24 hours to diagnose perinephric hematoma.

Results: Total 75 biopsies (blind $=37$ and Ultrasound -guided $=38$ ) were evaluated. Blind and Ultrasound-guided technique had significant difference of number of attempt (mean \pm SD) $2.4 \pm 0.6$ and $2.1 \pm 0.3(\mathrm{p}<0.01)$ respectively with no difference of number of glomeruli in light microscopy. Bleeding complications were macroscopic hematuria $(11(30 \%) v s 15(40 \%))$ and perinephric hematoma ( 5(13.5\%)vs3(7.9\%)) in blind and Ultrasound-guided technique respectively with no significant difference. Those patients who developed perinephric hematoma was observed in all at 6 hours.

Conclusions: Ultrasound-guided technique of percutaneous renal biopsy is superior with fewer attempts and equivalent in adequacy of tissue and bleeding complication than blind technique.

Keywords: Biopsy complications; percutaneous renal biopsy; perinephric hematoma; ultrasound-guided renal biopsy.

\section{INTRODUCTION}

Percutaneous renal biopsy(PRB) and histopathological evaluation is a mandatory tool for definitive diagnosis and prediction of prognosis of renal parenchymal diseases.

Adequate tissue yield with at least 8-10 glomeruli with no or minor bleeding complications have always been the goal. ${ }^{1,2}$ Historically, PRB was performed blindly by radiography ${ }^{3}$ and later ultrasound(USG) guided surface marking. Gradually the whole procedure of PRB has been performed by real-time USG guidance with better tissue yield and increased safety. ${ }^{4,5}$

Similarly, PRB started in 1973 by nephrologist in Nepal had evolved from blind technique via radiography ${ }^{6}$ and then USG guided surface markingto real-time USG guided technique and histopathological diagnosis of kidney disease been reported after $2000 .^{7-9}$ So, present study

was conducted to compare the efficiency, adequacy of tissue and bleeding complications between blind and real time USG-guided PRB.

\section{METHODS}

This was a cross sectional, randomized, comparative study conducted in the Department of Nephrology, Bir Hospital, Kathmandu, Nepal from June 2016 to December 2016. Ethical approval was obtained from Institutional Review Board (IRB) of National Academy of Medical Sciences (NAMS).

Patients decided for kidney biopsy by consultant nephrologist with bilateral normal sized kidneys and normal bleeding profiles (BT, CT, PT, APTT, and Platelets) were included after obtaining informed written consent and patients with single kidney and allograft was excluded.
\end{abstract}

Correspondence: Dr Anil Pokhrel, Department of Nephrology, National Academy of Medical Sciences, Bir Hospital, Kathmandu, Nepal. Email: anilpokhrel@gmail.com, Phone: +9779840050269 . 
Detail history including drug history was taken and blood pressure recorded. Patients on antiplatelet or anticoagulant drugs were asked to stop it for 5 days after approval from concerned physician and follow up for enrolment. All patients undergoing PRB were admitted. The laboratory parameters including bleeding profiles and renal function tests and clinical indications for PRB were recorded in predesigned pro-forma. The first patient was randomized by a coin-toss and underwent blind biopsy: subsequent patients were randomized alternately.

All PRB were performed by second year nephrology residents who were trained for the procedure already. The patients were kept on prone position. A routine preliminary USG with $3.5 \mathrm{MHZ}$ transducer had scanned both kidneys for complete evaluation of cortical and sinus echogenicity by longitudinal and transverse images and exclusion of any structural abnormalities prior to the biopsy. All PRB were performed by Bard gun "maxcore" disposable core biopsy instrument (Bard Peripheral Vascular, Inc, USA), size $18 \mathrm{G}^{*} 16 \mathrm{~cm}$ length, with $1.8 \mathrm{~cm}$ sample notch length.

For blind biopsy, USG surface marking for PRB over the lower pole of the left kidney by default were done and the perpendicular distance from the skin to the renal cortex were measured. The skin was disinfected with povidone-iodine, draped with a sterile sheet and anesthetized with $1 \%$ lignocaine. A probe was used to locate the kidney depth. Patients were asked to take deep breath in and hold and probe inserted perpendicularly until it penetrated the muscle and reached the expected distance estimated by the initial USG. Then patients were asked to take deep breath in and out to see the movement of the probe. If it was not moving with respiration, again patient was asked to hold deep breath in and probe pushed slightly more. The process repeated until the probe penetrated the kidney and moved with respiration. Then the probe was removed and depth measured in Bard gun and it was inserted blindly up to that depth with breath hold in deep inspiration, gun fired and tissue obtained.

USG probe was covered with a sterile cover and sterile jelly applied. Local anesthesia with $1 \%$ lignocaine was injected under USG guidance from the skin to the renal capsule. The Bard gun was advanced under USG guidance along the anesthetized tract. Biopsies were performed free hand and biopsy adapter was not used. Before the renal capsule reached, the patient was instructed to take a breath and hold it such that the lower pole comes under the needle tip, and then it was advanced and the gun was fired.

The USG surface marking with depth measurement from skin in blind biopsy and real time biopsy needle visualization at the renal capsule in USG-guided technique is shown in Figure 1.

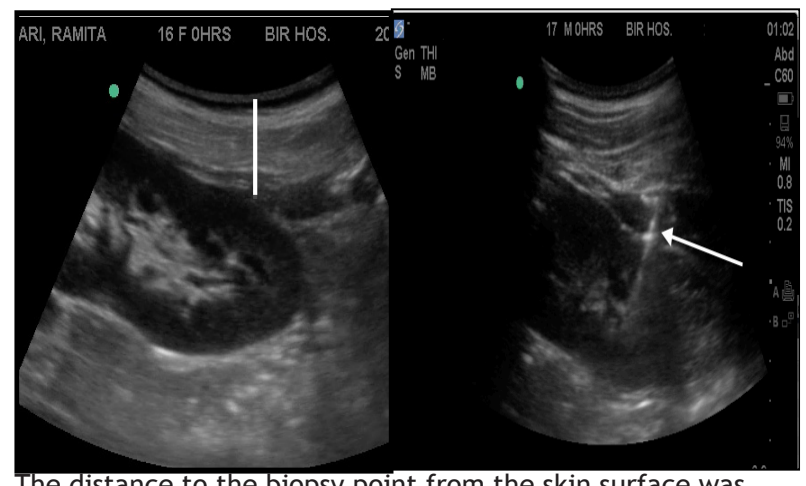

The distance to the biopsy point from the skin surface was determined (white line). Real time biopsy needle visualization (arrow)

Figure 1. B mode ultrasonographic image of a kidney.

In general, 2 cores of tissues were taken. A minimum of two attempts and a maximum of four attempts were performed in each of these patients. After the procedure, a firm pressure was applied.

The renal tissue obtained was sent for light-microscopy and direct immunofluorescence (DIF). Wound was closed with dressing.

After the procedure, all patients were advised for strict bed rest lying flat on the back for 6 to 8 hours and then remained in bed for 24 hours of observation. Patients were monitored closely after biopsy for signs or symptoms of complications, such as hematuria, flank pain, or hypotension. Vital signs was checked every 15 min for $1 \mathrm{~h}$, every hour for $2 \mathrm{~h}$, every $2 \mathrm{~h}$ for $4 \mathrm{~h}$, and then every $4 \mathrm{~h}$ thereafter. Each urine void was checked for hematuria visually, and the result was recorded. Hemoglobin levels were checked at approximately 18 to $24 \mathrm{~h}$ after the procedure. Data was entered first in excel spread sheet and later analysed using SPSS software package 19.0 and $p<0.05$ was taken as the level of significance.Data for continuous variables was expressed as mean \pm standard deviation and t-test was used to compare the mean difference of each group. Test suitable for $2 \times 2$ contingency table (chi-square) was used for test of independence. 


\section{RESULTS}

Total 76 patients had undergone PRB of native kidneys during study period with blind biopsy in 38 (15 male and 23 female) and USG -guided in 38 (24 male and 14 female) patients. But one patient in blind group was excluded from the study as there was no tissue even after 4 attempts with 75 PRB for analysis.

The comparison of clinical and laboratory parameters of patient with blind and USG-guided biopsy (Table 1) has shown no difference in age,hemoglobin, platelet counts, BT, PT and APTT and significantly higher baseline systolic and diastolic blood pressure and lower $\mathrm{CT}$ in USG guided group though all within normal limit and the patients were of more female gender in blind group. The indications for PRB were nephrotic syndrome (44\%), glomerulonephritis (GN) with nephritic syndrome (16\%) and others (40\%) with no difference between two groups (Fig 2).

\begin{tabular}{|c|c|c|c|}
\hline & $\begin{array}{r}\text { Blind PRB } \\
(n=37)\end{array}$ & $\begin{array}{l}\text { USG Guided } \\
\text { PRB }(n=38)\end{array}$ & $\begin{array}{c}\text { p- } \\
\text { values }\end{array}$ \\
\hline Age (Years) & $32.97 \pm 15.56$ & $33.92 \pm 15.41$ & 0.792 \\
\hline $\begin{array}{l}\text { Male gender } \\
\mathrm{n}(\%)\end{array}$ & 15 (41\%) & $24(63 \%)$ & 0.05 \\
\hline $\begin{array}{l}\text { SBP }(m m \text { of } \\
\mathrm{Hg})\end{array}$ & $123.19 \pm 17.18$ & $130.42 \pm 10.56$ & 0.031 \\
\hline DBP & $79.03 \pm 10.12$ & $83.68 \pm 8.63$ & 0.035 \\
\hline $\begin{array}{l}\text { Platelet } \\
\text { count }(x 1000 \\
/ \mathrm{mm} 3)\end{array}$ & $274 \pm 93$ & $267 \pm 125$ & 0.777 \\
\hline
\end{tabular}

$\begin{array}{lrrr}\text { BT (Min) } & 2.88 \pm 0.82 & 2.64 \pm 0.74 & 0.241 \\ \text { CT }(\text { Min) } & 7.65 \pm 1.25 & 6.89 \pm 1.37 & 0.016 \\ \text { PT (s) } & 12.51 \pm 1.61 & 12.37 \pm 1.30 & 0.686 \\ \text { APTT (s) } & 32.39 \pm 8.10 & 33.87 \pm 10.31 & 0.493\end{array}$

Analysis of renal biopsy efficiency and adequacy of tissue (Table 2) has shown real time USG- guided technique being more efficient than blind technique with mean number of attempts (2.11 versus $2.41, p=0.008)$ and patients with more than 2 attempt needed in (4 versus 13, $p=0.011$ ) respectively. But there was no difference in adequacy of tissue with similar number of tissue bits per attempt, average size of the bits and average total number of glomeruli in both techniques. Moreover, tissue adequacy with $>8$ glomeruli was found in $94.6 \%$ of blind and $92.1 \%$ of USG guided biopsies. But in one case of blind biopsy, there was only medullary tissue with no glomeruli in DIF study and repeat biopsy was done.

The bleeding complications (perinephric hematoma and / or macroscopic hematuria), as shown in Table 3 were observed in $35.1 \%$ of blind and $42.1 \%$ of USG guided PRB with macroscopic hematuria being the predominant complication in $29.7 \%$ vs $39.5 \%$ patients respectively and none of the patients in both group had persistent macroscopic hematuria till 24 hours after PRB. The perinephric hematoma was found only in $13.5 \%$ of blind and $7.9 \%$ of USG group and associated with macroscopic hematuria in $8.1 \%$ and $5.3 \%$ patients respectively. Moreover, the hematomas developed in all patients by 6 hours except one in blind technique that showed $2 \mathrm{~cm}$ hematoma at 24 hours and one patient in each group had persistent hematoma till 24 hours.

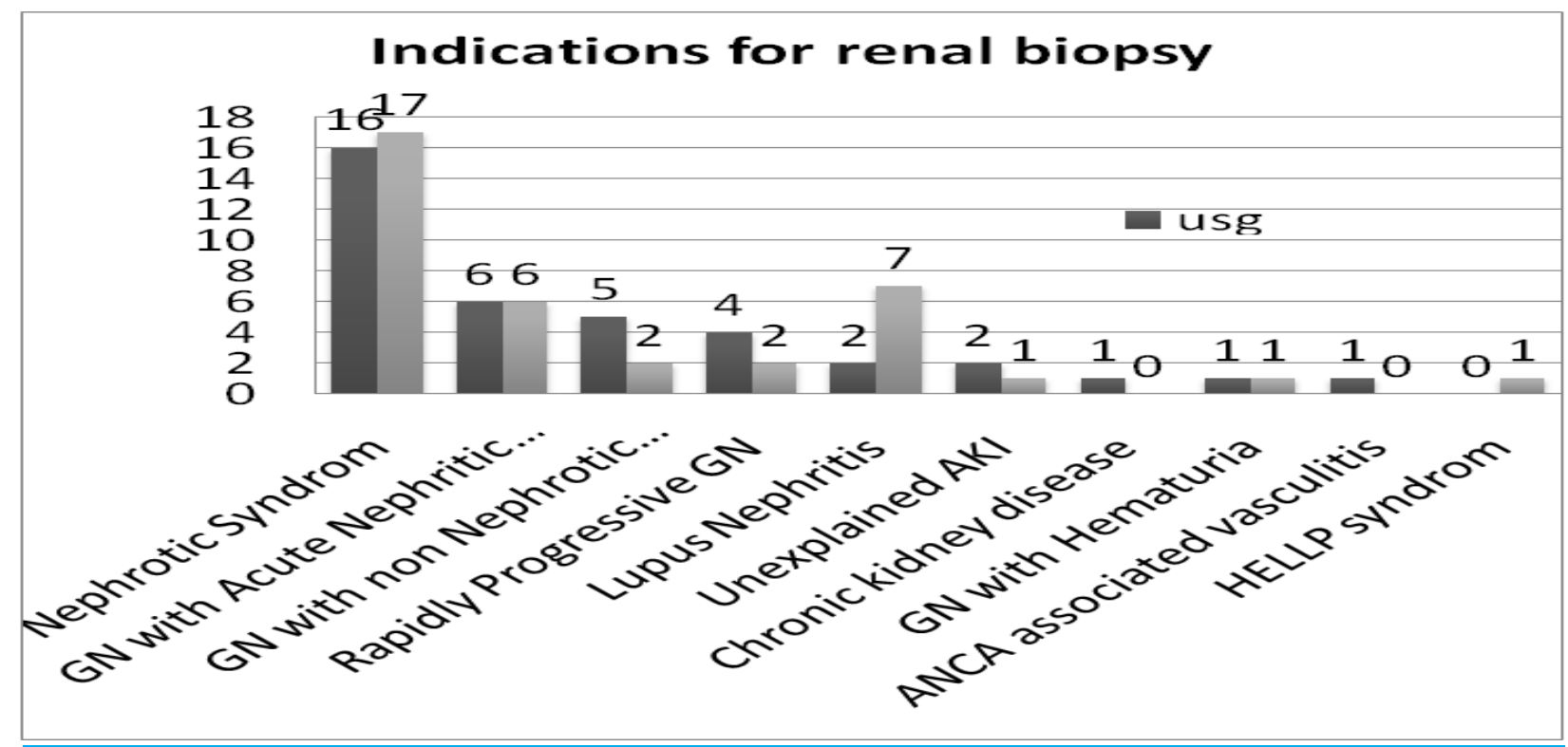

Figure 2. Indications for renal biopsy. 


\begin{tabular}{|c|c|c|c|}
\hline $\begin{array}{l}\text { Efficiency and } \\
\text { adequacy of } \\
\text { tissue }\end{array}$ & $\begin{array}{r}\text { Blind PRB } \\
(n=37)\end{array}$ & $\begin{array}{l}\text { Real time } \\
\text { USG guided } \\
\text { PRB }(n=38)\end{array}$ & $\begin{array}{r}p- \\
\text { values }\end{array}$ \\
\hline $\begin{array}{l}\text { Total Number of } \\
\text { Attempts }\end{array}$ & $2.41 \pm 0.6$ & $2.11 \pm 0.3$ & 0.008 \\
\hline $\begin{array}{l}>2 \text { Attempts } \\
\text { needed }\end{array}$ & $\begin{array}{r}13 \\
(35.13 \%)\end{array}$ & $4(10.52 \%)$ & 0.011 \\
\hline $\begin{array}{l}\text { Number of tissue } \\
\text { bits per attempt }\end{array}$ & $0.95 \pm 0.13$ & $0.98 \pm 0.08$ & 0.198 \\
\hline $\begin{array}{l}\text { Average size of } \\
\text { the bits }(\mathrm{cm}) \text { per } \\
\text { sample }\end{array}$ & 1.0 & .31 & 0.281 \\
\hline $\begin{array}{l}\text { Total number of } \\
\text { glomeruli }\end{array}$ & $23.54 \pm 8.32$ & $23.89 \pm 10.01$ & 0.868 \\
\hline $\begin{array}{l}\text { Average number } \\
\text { of glomeruli per } \\
\text { sample }\end{array}$ & $10.72 \pm 4.07$ & $11.76 \pm 5.09$ & 0.331 \\
\hline $\begin{array}{l}>8 \text { glomeruli in } \\
\text { light microscopy }\end{array}$ & $35(94.6 \%)$ & $35(92.1 \%)$ & 1.0 \\
\hline
\end{tabular}

\section{Table 3. Bleeding Complications of PRB.}

\begin{tabular}{|c|c|c|c|c|c|}
\hline Bleeding com & plicá & ions & \multicolumn{2}{|c|}{ PRB techniques } & $\begin{array}{l}P \\
\text { value }\end{array}$ \\
\hline \multicolumn{6}{|l|}{ Blind $(n=37)$} \\
\hline \multicolumn{6}{|c|}{ USG -guided $(n=38)$} \\
\hline \multirow{4}{*}{$\begin{array}{l}\text { Perinephric } \\
\text { Hematoma } \\
\text { (a) }\end{array}$} & \multicolumn{2}{|l|}{ No } & 32 & 35 & \\
\hline & \multirow{3}{*}{ Yes } & $\begin{array}{l}\text { At } 6 \\
\text { hours }\end{array}$ & $\begin{array}{l}4 \\
(10.8 \%)\end{array}$ & $3(7.9 \%)$ & 0.97 \\
\hline & & $\begin{array}{l}\text { New } \\
\text { at } 24 \\
\text { hours }\end{array}$ & $\begin{array}{l}1 \\
(2.7 \%)\end{array}$ & $0(0 \%)$ & \\
\hline & & Total & $\begin{array}{l}5 \\
(13.5 \%)\end{array}$ & $3(7.9 \%)$ & 0.68 \\
\hline \multirow{3}{*}{$\begin{array}{l}\text { Macroscopic } \\
\text { hematuria }\end{array}$} & \multicolumn{2}{|c|}{$\begin{array}{l}\text { Only } \\
\text { hematuria } \\
\text { (b) }\end{array}$} & $\begin{array}{l}8 \\
(21.6 \%)\end{array}$ & $\begin{array}{l}13 \\
(34.2 \%)\end{array}$ & \\
\hline & \multicolumn{2}{|c|}{$\begin{array}{l}\text { With } \\
\text { hematoma }\end{array}$} & $\begin{array}{l}3 \\
(8.1 \%)\end{array}$ & $2(5.3 \%)$ & \\
\hline & \multicolumn{2}{|c|}{ Total } & $\begin{array}{l}11 \\
(29.7 \%)\end{array}$ & $\begin{array}{l}15 \\
(39.5 \%)\end{array}$ & 0.21 \\
\hline \multicolumn{3}{|c|}{$\begin{array}{l}\text { Total bleeding } \\
\text { complication }(a)+(b)\end{array}$} & $\begin{array}{l}13 \\
(35.1 \%)\end{array}$ & $\begin{array}{l}16 \\
(42.1 \%)\end{array}$ & \\
\hline \multicolumn{3}{|c|}{ Post PRB interventions } & $0 \%$ & $0 \%$ & \\
\hline
\end{tabular}

The mean hemoglobin level ( $\mathrm{gm} / \mathrm{dl})$ at baseline and 1824 hours post PRB of blind $(12.2+2.2$ vs $12.0+2.0, p=0.10)$ and USG guided $(12.1+2.0$ vs $11.9+1.9, \mathrm{p}=0.11)$ showed insignificant blood loss in both techniques though there was reduction of hemoglobin in both group. There were no severe complications like blood loss requiring blood transfusion, loss of kidney function or death in any patients of both groups.

\section{DISCUSSION}

Percutaneous renal biopsy (PRB) with light and immunofluorescence examination of renal tissue can diagnose majority of renal parenchymal diseases. Addition of electronic microscopy with ultra-structural analysis provides invaluable information for accurate diagnosis of some specific renal diseases. ${ }^{10}$ PRB by blind technique is performed only by nephrologists and USG guided done by both nephrologist and radiologists or radiologist alone in different institutes as per their expertise.

In Nepal, this process was performed by nephrologists in the very beginning by blind technique through skin surface marking from X-ray KUB (Kidney, Ureter, Bladder) or nephrogram film by themselves and later through USG surface marking made by radiologists. Currently, with the availability of portable USG machines and development of expertise, it is either performed by realtime USG guidance by nephrologists or with assistance of radiologist or solely by radiologist. Although, histopathological diagnosis of glomerular disease, ${ }^{7-9}$ cast nephropathy ${ }^{11}$ and allograft nephropathy ${ }^{12}$ has been reported, there are few reports describing the PRB technique by radiologists and/or by nephrologist along with efficiency and complication of technique. ${ }^{13,14}$

We found that real-time ultrasound- guided renal biopsy was more efficient than blind technique with significantly less number of attempts to yield two adequate tissues $(p=0.008)$ for light microscopic and immunofluorescence study and two tissue bits were obtained by two attempts in $89 \%$ of patients in USG guided group compared to $65 \%$ in blind group $(p=0.011)$. Technical advantage of real time USG guided renal biopsy with two attempts in $91 \%$ patients were also observed by Maya and Allon in biopsy of 100 patients. ${ }^{15}$

Moreover, superiority of USG guided technique in adequacy of tissue with significantly higher number of glomeruli and success in $100 \%$ compared to $84 \%$ needing repeat biopsy in blind group was reported on a retrospective analysis. ${ }^{5}$ But in our study, there was no difference of adequacy of tissue as measured by number of tissue bits per attempt, average size of the bits per sample, total number of glomeruli, average number of glomeruli per sample and more than 8 glomeruli in sample for light microscopy in both technique and repeat biopsy was needed only in one patient in blind group for IF study indicating not inferiority of USG marked blind technique in tissue yield. 
Similarly, comparison of tissue yield by blind $(n=271)$ and USG guided $(n=170)$ renal biopsy performed by nephrologist in Korea also showed no difference though significantly better yield by both techniques compared to USG technique performed by radiologist. ${ }^{16}$ Total number of PRB attempt, mean size of renal tissue and average number of glomeruli was also reported to be significantly higher in USG guided PRB performed by nephrologist when compared with historic biopsies performed with radiology assistance indicating nephrologist should take up this simple but vital procedure. ${ }^{17}$ There are reports on USG guided PRB by radiologist with adequate tissue yield in $98.9 \%$ and by nephrology resident who were assisted by radiologist if unsuccessful with total adequate tissue yield in $92.3 \%$ from teaching institutes of Nepal. ${ }^{13,14}$ But in our institute as PRB has been always performed by nephrologist and trained the junior, the PRB by nephrology resident by self USG marking and self USG guided technique found to be efficient and effective with success rate of $98.7 \%$ of total biopsy.

The current practice of percutaneous native kidney biopsy is a relatively safe procedure with life threatening complications occurring in $<0.1 \%$ of biopsies. ${ }^{18}$ Bleeding complications as measured by macroscopic hematuria, perinephric hematoma, reduction of hemoglobin and need of intervention including blood transfusion or embolization revealed no significant difference in both techniques irrespective of needle bore size ${ }^{19}$ or irrespective of the specialty of the PRB performer. ${ }^{16}$ But better safety profile of USG guided technique compared to blind technique was observed in terms of large hematoma ( $0 \%$ vs $11 \%)$, vascular intervention ( $0 \%$ vs $8 \%$ ) and significantly higher 24 hour post biopsy hematocrit $(p=0.04)$ in study by Maya et al, ${ }^{5}$ and lower frequency of perinephric hematoma with smaller hematoma volume by Kim et al. ${ }^{20}$ We found perinephric hematoma in $10.7 \%$ patients all being minor needing no intervention with no difference between two techniques indicating blind technique is equally safe if performed by well-trained person.

Macroscopic hematuria is the most common and usually transient complication ${ }^{21}$ and may be associated clots, colicky pain, urinary obstruction and in the most severe case hemorrhagic shock. Puncture of the renal calyceal system, large vessel damage, arteriovenous fistulas and aneurysms are the main causes. In our study frank hematuria occurred in $30 \%$ of blind and $40 \%$ of USG guided biopsies with no statistical difference and all resolved by 24 hours.

Lower hemoglobin value clinically predicts a major bleed. Some study shows each $1 \mathrm{gm} / \mathrm{dl}$ decrease in the baseline hemoglobin doubled the likelihood of a major bleed $^{22}$ and other shows drop in hemoglobin by $>1 \mathrm{~g} / \mathrm{dl}$ after biopsy is common and has been reported to occur in almost $50 \%$ of cases. ${ }^{23,}{ }^{24}$ Our study also showed mild decrease in hemoglobin by $0.2 \mathrm{gm} / \mathrm{dl}$ in both groups needing no blood transfusion. The cause of the nonhemorrhagic change in hemoglobin is not known but may be the result of multiple factors, including the frequent development of a small subclinical perinephric hematoma, hemodilution as a result of the more water intake, ${ }^{25}$ or postural hemodilution resulting from the resorption of interstitial fluid in severely edematous patients after prolonged bed rest after biopsy. ${ }^{26}$ Thus, an initial decrease in hemoglobin concentration after renal biopsy must raise suspicion for a possible complication, but it is not a reliable predictor of outcome.

In a smaller retrospective series, Simard-Meilleur et al. found that $100 \%$ of complications in outpatients undergoing PRB occurred within 8 hours versus $72 \%$ of complications in inpatients and that $10 \%$ of inpatients had complications $>24$ hours after PRB. ${ }^{27}$ The most recent large biopsy series found that $91 \%$ of major complications occurred within 12 hours of PRB, with $7.4 \%$ occurring between 12 and 24 hours and $1.85 \%$ occurring after 24 hours $^{28}$ where as other study shows only two hours post-PRB observation is optimal time to assess the safety of PRBs and prediction of late complications. ${ }^{29}$ In our study also perinephric hematoma was observed in all at 6 hours except one in blind technique who showed it in 24 hours and none needed any intervention.

\section{CONCLUSIONS}

Compared with the blind technique, real time USGguided percutaneous renal biopsy was superior in terms of fewer attempts; however there was no difference in the adequacy of sample and bleeding complications.

\section{REFERENCES}

1. Fogo AB. Approach to renal biopsy. Am J Kidney Dis. 2003;42(4):826-36.

2. Mahajan V, Suri D, Saxena A, Nada R. Should ultrasound guided percutaneous renal biopsy in children be done in a day care setting?. Indian J Nephrol. 2010;20(1):21. [Full Text]

3. Iversen P, Brun C. Aspiration biopsy of the kidney. Am J Med. 1951;11(3):324-30.[Pub Med] 
4. Hergesell O, Felten H, Andrassy K, Kühn K, Ritz E. Safety of ultrasound-guided percutaneous renal biopsyretrospective analysis of 1090 consecutive cases. Nephrol Dial Transplant. 1998;13(4):975-7.[Pub Med]

5. Maya ID, Maddela P, Barker J, Allon M. Percutaneous Renal Biopsy: Comparison of Blind and Real-Time UltrasoundGuided Technique. Semin Dial. 2007;20(4):355-8.[Full Text]

6. Hada R. End stage renal disease and renal replacement therapy-challenges and future prospective in Nepal. J Nepal Med Assoc. 2009;48(176):344-8.[Full Text]

7. Khakurel S, Agrawal R, Hada R. Pattern of glomerular disease in Nepal: A single-center experience. Saudi J Kidney Dis Transplant. 2015;26(4):833-38.[Full Text]

8. Ghimire M, Pahari B, Paudel N, Das G, Das GC, Sharma SK. Kidney biopsy: An experience from tertiary hospital. Saudi J Kidney Dis Transplant. 2014;52(193):707-12.[Full Text]

9. Aryal G, Kafle R. Hisopathological spectrum of glomerular disease in nepal: a seven-year retrospective study. Nepal Med Coll J. 2008;10(2):126-8.[Full Text]

10. Mokhtar GA, Jallalah SM. Role of electron microscopy in evaluation of native kidney biopsy: a retrospective study of 273 cases. Iranian J Kidney Dis. 2011;5(5):314-9. [Full Text]

11. Hada R, Poudyal B, Sharma A, Khatri R. Lambda light chain myeloma with oliguric cast nephropathy and remission with bortezomib, Doxorubicin and dexamethasone. J Nepal Med Assoc. 2012;52(188):192-5.[Full Text]

12. Aryal G, Shah D. Histopathological evaluation of renal allograft biopsies in Nepal: interpretation and significance. Journal of Pathology of Nepal. 2012;2(3):172-9. [Full Text]

13. Chataut D, Subedi K, Lohani B. A Study of Diagnostic Yield, Efficancy and Complications of Ultrasound Guided Renal Biopsy in Different Renal Pathologies. Journal of Institute of Medicine. 2014;37(1):58-63.[Full Text]

14. Maskey A, Bhoomi KK. USG assisted and USG guided percutaneous renal biopsy at Nepal Medical College Teaching Hospital: A three and half years study. Nepal Med Coll J. 2014;16(1):26-9.[Full Text]

15. Maya ID, Allon M. ASDIN: Percutaneous renal biopsy: outpatient observation without hospitalization is safe. Semin Dial. 2009;22(4): 458-61. [Full Text]
16. Chung S, Koh ES, Kim SJ, Yoon HE, Park CW, Chang YS, et al. Safety and tissue yield for percutaneous native kidney biopsy according to practitioner and ultrasound technique. BMC Nephrol. 2014;15(1):96. [Full Text]

17. Yesudas S, Georgy N, Manickam S, Raheena A, Monai R, Noble B, et al. Percutaneous real-time ultrasound-guided renal biopsy performed solely by nephrologists: A case series. Indian J Nephrol. 2010;20(3):137-141[Full Text]

18. Brachemi S, Bollée G. Renal biopsy practice: what is the gold standard?. World J Nephrol. 2014;3(4):287. [Full Text]

19. Ali H, Murtaza A, Anderton J, Ahmed A. Post renal biopsy complication rate and diagnostic yield comparing hands free (ultrasound-assisted) and ultrasound-guided biopsy techniques of renal allografts and native kidneys. Springerplus. 2015;4(1):491.[Full Text]

20. Kim D, Kim H, Shin G, Ku S, Ma K, Shin S, et al. A randomized, prospective, comparative study of manual and automated renal biopsies. Am J Kidney Dis. 1998;32(3):426-31. [Science Direct]

21. Whittier WL. Complications of the percutaneous kidney biopsy. Adv Chronic Kidney Dis. 2012;19(3):179-87.

22. Marwah DS, Korbet SM. Timing of complications in percutaneous renal biopsy: what is the optimal period of observation? Am J Kidney Dis. 1996;28(1):47-52. [Science Direct]

23. Burstein DM, Korbet SM, Schwartz MM. The use of the automatic core biopsy system in percutaneous renal biopsies: a comparative study. Am J Kidney Dis. 1993;22(4):545-52. [Science Direct]

24. Khajehdehi P, Junaid SM, Salinas-Madrigal L, Schmitz PG, Bastani B. Percutaneous renal biopsy in the 1990s: safety, value, and implications for early hospital discharge. Am J Kidney Dis. 1999;34(1):92-7.[Science Direct]

25. Bolton WK. Nonhemorrhagic decrements in hematocrit values after percutaneous renal biopsy. JAMA. 1977;238(12):1266-8[Full Text]

26. Clive DM. Postural hemodilution in nephrotic edema: a cause of spurious hemorrhage after renal biopsy. Am J Kidney Dis. 1997;29(4):627-30.[Science Direct]

27. Simard-Meilleur MC, Troyanov S, Roy L, Dalaire E, Brachemi S. Risk factors and timing of native kidney biopsy complications. Nephron Extra. 2014;4(1):42-9.[Full Text] 
28. Prasad N, Kumar S, Manjunath R, Bhadauria D, Kaul A, Sharma RK, Gupta A, Lal H, Jain M, Agrawal V. Realtime ultrasound-guided percutaneous renal biopsy with needle guide by nephrologists decreases post-biopsy complications. Clin Kidney J. 2015;8(2):151-6.[Full Text]
29. Habas E, Elhabash B, Rayani A, Turgman F, Tarsien R. Post-Percutaneous Renal Biopsy Observation Time; Single Center Experience. Austin J Nephrol Hypertens. 2016;3(2):1058.[Full Text] 